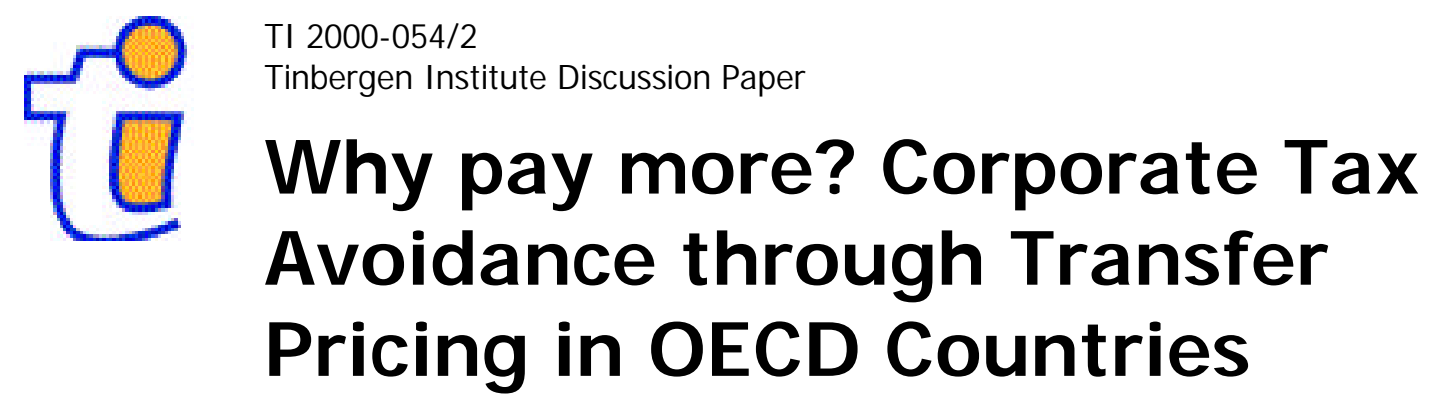

Eric J. Bartelsman

Roel M.W.J . Beetsma 
Tinbergen Institute

The Tinbergen Institute is the institute for economic research of the Erasmus Universiteit Rotterdam, Universiteit van Amsterdam and

Vrije Universiteit Amsterdam.

Tinbergen I nstitute Amsterdam

Keizersgracht 482

1017 EG Amsterdam

The Netherlands

Tel.: +31.(0)20.5513500

Fax: $\quad+31 .(0) 20.5513555$

Tinbergen I nstitute Rotterdam

Burg. Oudlaan 50

3062 PA Rotterdam

The Netherlands

Tel.: $\quad+31 .(0) 10.4088900$

Fax: $\quad+31 .(0) 10.4089031$

Most TI discussion papers can be downloaded at

http://www.tinbergen.nl 


\title{
Why pay more? Corporate tax avoidance through transfer pricing in OECD countries*
}

\author{
ERIC J. BARTELSMAN \\ Free University Amsterdam \\ Roel M. W. J. Beetsma \\ University of Amsterdam and CEPR
}

June 26, 2000

\begin{abstract}
This paper presents evidence of profit shifting in response to differences in corporate tax rates for a large selection of OECD countries. In our estimates we control for the effects of tax rate changes on real activity. Our baseline estimates suggest that, on average, a unilateral increase in the corporate tax rate does not lead to an increase in corporate tax revenues owing to a more than offsetting decline in reported profits.
\end{abstract}

Keywords: Profit shifting, transfer pricing, corporate tax rates, STAN database.

JEL: F2, H2

\footnotetext{
${ }^{*}$ We thank Ruud de Mooij and seminar participants at the Netherlands Bureau for Economic and Policy Analysis (CPB) for helpful comments. Part of this paper was written while Beetsma was visiting CES (University of Munich). He thanks his host institution for their hospitality and their excellent research environment. In particular, he thanks Alfons Weichenrieder for stimulating discussions.

$\dagger$ Mailing address: ESI, Department of Economics, Free University of Amsterdam, De Boelelaan 1005, $1081 \mathrm{HV}$ Amsterdam, phone: +31.20.4446080, fax: +31.20.4446127, e-mail: ebartelsman@econ.vu.nl.

${ }^{\sharp}$ Mailing address: Department of Economics, University of Amsterdam, Roetersstraat 11, 1018 WB Amsterdam, The Netherlands, phone: +31.20 .5255280 , fax: +31.20 .5254254 , e-mail: Beetsma@fee.uva.nl.
} 


\section{Introduction}

The debate over tax competition versus tax coordination is of increasing relevance to decision makers in central and decentral policy arenas. Central authorities worry about the direct loss of real resources associated with pure tax arbitrage activities and about the erosion of a part of the tax-base resulting from a possible race to the bottom for corporate taxes. Yet, they also are mindful of the difficult political dynamics of controlling efficiency of the aggregate public sector under a system of coordinated rates. Decentral authorities profess to prefer competing for business based on overall locational characteristics, which include a balance between taxes and public provisions. Nevertheless, each decentral government has an incentive to use tax policy to draw in mobile production factors and to complain to the central authority about such behavior from other decentral governments.

This paper provides a small piece of empirical evidence needed to further the debate. We do not address the issue of how, and how much, tax rates and tax differences affect the allocation of real economic resources within and between jurisdictions. The paper does isolate and quantify pure profit shifting between locations induced by differences in corporate tax rates. ${ }^{1}$ The potential scope for profit shifting is sizeable because of the ongoing economic integration and the increasing volume of trade in intermediate goods. Casual observation underlines the importance of the issue. For example, Weichenrieder (1996) discusses some cases of profit shifting out of Germany, which for a long time has had the highest corporate tax rate among the G7 countries. A particularly interesting example is BMW, the German car producer, whose tax payments in Germany as a share of its worldwide tax payments dropped from 88\% in 1988 to $5 \%$ in 1992 and $-16 \%$ in 1993. BMW's financial director publicly stated that his corporation tried to shift costs to where taxes were highest, which was Germany. ${ }^{2}$

The evidence is that the amount of profit shifting actually taking place is both statistically and economically significant across a variety of different empirical specifications. Our baseline estimates suggest that, on average, a unilateral increase in the corporate tax rate does not lead to an increase in corporate tax revenues owing to a more than offsetting decline in reported profits. Actually, a back-of-the-envelope calculation suggests that, compared to when profit shifting is absent, a unilateral one-percentage point increase in the corporate tax rate leads to a $3 \%$ reduction in corporate tax revenues.

The paper closes with some policy advice, partly based on the presented evidence and partly based on economic reasoning. In any case, increasing the ex-

\footnotetext{
${ }^{1}$ From now on we refer to "profit shifting" or "income shifting" as the shifting of reported profits without any corresponding change in real activity.

${ }^{2}$ Handelsblatt, 26 March 1993, p.2.
} 
pected cost to business of misrepresenting profits, either through increased monitoring or through increased penalties, should lower the measured leakage effect.

The research reported in this paper not only provides evidence relevant to policy makers, but contributes to the academic debate on international tax issues as well as to that on international productivity comparisons. While quite some empirical work has been done on profit shifting of U.S. multinationals, hardly any such work has been done for the other OECD countries. Further, previous work has either been concerned with individual firms in two countries, or with macroeconomic data in multiple countries. This paper takes an in-between position and considers evidence for disaggregated industrial sectors for a group of industrialized countries. Finally, this paper develops a novel method for isolating the pure effects of profit shifting, by controlling for the effects of taxes and unobserved productivity on real resource allocation.

Our contribution to international productivity comparisons may not seem evident at first glance. However, profit shifting or income shifting between countries for tax purposes introduces distortions in measured productivity: sales in a low tax country may be over-reported and intermediate inputs under-reported. Without changes in underlying technology and assuming correct measurement of price deflators, the shifting of income and expenses will lead to increases in measured productivity in a country that lowers its corporate tax rate. This observation has been made in the comparison of productivity between similar firms in Ireland and the U.K (Birnie, 1996). We use this insight as motivation for our strategy to estimate the magnitude of income shifting.

The remainder of the paper is structured as follows. Section 2 discusses the related literature. Section 3 motivates the empirical model, while section 4 describes the data. Section 5 presents and discusses the empirical results. Finally, section 6 concludes the main body of the paper.

\section{Related literature}

Tax revenues depend on tax rates and the tax base. While tax rates are under the control of the fiscal authorities, the tax base is endogenous and may change as tax rates change. In the simplest possible model of a closed economy, an increase in the corporate tax rate reduces the return on capital and, hence, the incentive to invest. Production or economic activity will, therefore, be lower. Matters are more complicated when economies are open and there is capital mobility. A fall in a country's tax rate not only raises overall economic activity in the world, it also attracts activity away from other countries. By opening up, a country might expect a rise in the elasticity of its tax base with respect to the corporate tax rate. 
Several empirical contributions in the literature have tried to assess the magnitude of the role played by tax rates. Hines (1996a) explores how state income taxes affect the source country of foreign investment in U.S. states. Investment shares of investors from countries that provide foreign tax credits for taxes paid in the U.S. are substantially larger in high-tax states. Devereux and Griffith (1998) find that, although tax rates do not seem to affect the decision of U.S. companies to produce in Europe or not, conditional on production in Europe they have a strong effect on the decision in which country to locate. A one-percent increase in the effective average tax rate reduces the probability of location by between $0.5 \%$ and $1.3 \%$.

In an open economy, tax rate differences can affect reported profits not only via their effect on real activity, but also can influence reported profits through the pure shifting of profits on paper. There is a variety of ways to shift profits. One possibility concerns the allocation of common expenses across different affiliates of the same multinational. Another way to shift profits is to finance new subsidiaries in high-tax countries with debt instead of equity. Of concern in this paper is the manipulation of transfer prices for cross-border intra-firm deliveries of goods and services. Although the OECD Model Tax Convention and the OECD Transfer Pricing guidelines call for the use of the "arm's length principle", ${ }^{3}$ in practice, the application of the principle is often problematic. For example, for many intra-firm transactions there exists no comparable market. This is in particular the case for intellectual property, developed by one part of the multinational company and used by other parts of the company in other countries.

The incentives for profit shifting depend in the first place on the difference in corporate tax rates between countries and the system that residence countries use to avoid double taxation. Everything else equal, the gains from profit shifting are largest for companies that reside in countries where the exemption system prevails (for example, France and the Netherlands). Once it has been taxed abroad, foreign income is exempted from home-country taxation. Under the so-called credit and deferral system (for example, Japan, the U.K. and the U.S.), companies receive a tax credit for taxes paid aborad. Gains from profit shifting primarily arise out of the fact that home tax payment is deferred until income is repatriated to the home country.

Excellent surveys of the literature can be found in Hines (1996b) and Newlon (1997). The literature suggests that for the U.S. profit shifting is relevant and often sizable. Some studies are based on country-level data. For example, Grubert and Mutti (1991) investigate the sensitivity of total foreign earnings of U.S.

\footnotetext{
${ }^{3}$ The arm's length principle requires prices for transactions between different parts of the same multinational to be set at same level as prices that are applied to similar transactions between unrelated parties.
} 
affiliates to corporate tax rates for a cross section of other countries. In a similar vein, Hines and Rice (1994) explore the relation between reported profitability of foreign affiliates of U.S.-controlled firms and host-country tax rates, while controlling for capital and labor inputs. Several studies that use firm level data also find evidence that is (in principle) consistent with income shifting. Harris et al. (1993) find that the presence of affiliates in low-tax countries is associated with lower tax liabilities in the U.S. Grubert (1998) detects a negative relationship between reported subsidiary income and the statutory corporate tax rate in the host country. Finally, Grubert and Slemrod (1998) focus on profit shifting of U.S. multinationals to Puerto Rico. Because of the so-called "possessions tax credit", income generated in Puerto Rico is in effect completely exempt from U.S. corporate taxation, while taxation by the Puerto Rican authorities is virtually negligible. One of the main features of the analysis is that it treats profit shifting and real investment as joint decisions, because more real investment facilitates profit shifting.

\section{Empirical motivation}

Profit shifting leads to differences between reported income and the "true" income generated by physical activity. Revenue from production is underreported (overreported) in countries with relatively high (low) tax rates, because the firm claims lower- (higher-) than-market prices for intra-firm international shipments of its products. Inversely, intermediates purchases may be underreported (overreported) by internationally operating firms in countries with relatively low (high) tax rates. Consequently, reported nominal value added ( $N V A$, revenue less intermediate purchases) in a country is negatively affected by the level of its corporate tax rate relative to trading partners. Profit shifting causes statistics on nominal value added collected by the tax authorities or statistical offices to be measured with error:

$$
N V A=P^{t r} Q^{*}
$$

where $Q^{*}$ is actual real value added and $P^{t r}$ is the implicit (and unobserved) price determined by this expression. It differs by a factor from the market price, or arms-length price $\left(P^{*}\right)$ :

$$
P^{t r}=P^{*} e\left(\tau^{D}\right), \text { where } \frac{\partial e}{\partial \tau^{D}}<0,
$$

where $\tau^{D}$ is the difference between the tax rate in the home country and the country with which intra-firm trade takes place. 
The statistical office uses proper price quotes on market transactions, so that price statistics and actual market, or arms-length, prices coincide: $P=P^{*}$, where $P$ is the product or materials price measured by the statistical office. Regardless of the method used to deflate value added, profit shifting caused by higher taxes will reduce the implicit transfer price $P^{t r}$ relative to the official deflator $P$. Real value added statistics $(Q)$ are thus contaminated with mismeasurement from income shifting, and therefore differ from actual real value added $\left(Q^{*}\right)$ by the factor $e\left(\tau^{D}\right)$ :

$$
Q=\frac{\mathrm{NVA}}{P}=Q^{*} e\left(\tau^{D}\right)
$$

In order to estimate the magnitude and significance of the income-shifting problem, one would need to determine actual real value added, $Q^{*}$, and find out whether it differs systematically with tax rates from reported real value added. Unfortunately, two practical problems stand in the way. First, actual real value added is not observed. Next, actual real value added may itself be affected by tax rates, because international firms make "greenfield" and expansion investment decisions based on average and marginal effective tax rates, respectively. The following derivation shows how we control for this in order to empirically identify $e\left(\tau^{D}\right)$ using observed data.

The basic insight for the estimation strategy comes from viewing the transfer pricing problem as an errors-in-variables problem in estimating a production function. The identification issue is to disentangle the mismeasurement component and the productivity residual component. ${ }^{4}$ Analogous to the approach of Roeger (1995) for disentangling mark-ups and productivity movements, we take a ratio of nominal output and nominal input expenses, in order to cancel out the unobserved productivity shock.

We start with a standard production function, and the first-order condition for profit maximization with respect to the labor inputs. Actual production is given by:

$$
Q^{*}=A F(K, L),
$$

where $K$ is capital and $L$ is labor input, and $A$ is unobserved (by the econometrician) productivity.

We assume that the multinational hires labor until the wage equals the marginal revenue product, valued at market prices:

$$
w=P^{*} \frac{\partial Q^{*}}{\partial L}
$$

\footnotetext{
${ }^{4}$ For an overview of some of the identification problems in estimating productivity, see Bartelsman and Doms (2000).
} 
With a Cobb-Douglas technology and constant returns to scale, in symbols $F(K, L)=$ $K^{1-\alpha} L^{\alpha}$, we get the following relationship between the observed (reciprocal of the) labor share and the factor $e$ :

$$
\frac{P Q}{w L}=\frac{1}{\alpha} e\left(\tau^{D}\right)
$$

where $\alpha$ is the output elasticity of labor from the Cobb-Douglas production function. Note that the unobserved productivity term $A$ cancels out. We refer to the left-hand side of (3.2) as the "value-labor ratio". The advantage of using (3.2) in the empirical analysis, is that we control for the effect that tax rates may have on the scale of operations. ${ }^{5}$ Under Cobb-Douglas, the scale of operations and the wage-rental ratio will not affect the labor share of income. The latter is no longer the case for a constant elasticity of substitution (CES) production technology, where an increase in the cost of capital as a result of tax rate changes implies a substitution towards labor. With a CES production technology, in symbols $F(K, L)=\left[\delta K^{\rho}+(1-\delta) L^{\rho}\right]^{1 / \rho}$, one has:

$$
\frac{P Q}{w L}=\left[1+c^{1 /(\rho-1)}\left(\frac{\tilde{r}}{w}\right)^{\rho /(\rho-1)}\right] e\left(\tau^{D}\right),
$$

where $c \equiv[\delta /(1-\delta)]$ depends on the CES parameters and $\tilde{r}$ denotes the taxdependent Jorgenson-Hall user cost of capital. Because the functional relation between taxes and the user cost of capital is well known, $\tilde{r}$ can be constructed from the available data, and only the CES parameters and the function $e\left(\tau^{D}\right)$ need to be estimated.

\section{The data}

We obtain our data from various sources. Data on labor compensation and valueadded are taken from the OECD's "Structural Analysis Database" (STAN). This is a sectoral database, which comprises many of the OECD countries (a list of the sectors and the countries included in the analysis can be found in the Appendix B). The maximum time series length covered by the STAN is 1970-1997. More details about the STAN can be found in OECD Statistics (1999). We take the long-term interest rate and the price deflator for investment from the annual economic indicators database of the OECD.

Headline corporate tax rates are obtained from various issues of PriceWaterhouseCoopers' International Tax Summaries. Figure 6.1 depicts headline rates for a subset of the OECD countries. The figure represents the main stylized facts for the full set of countries used in our analysis. First, there has been a downward

\footnotetext{
${ }^{5}$ Appendix A presents an example of a more rigorous microfoundation for relationship (3.2).
} 
trend in corporate tax rates (this is confirmed by the unweighted average corporate tax rate, which falls from $44.5 \%$ in 1979 to $35.1 \%$ in 1997). In particular, countries that started the sample period with high corporate tax rates, such as Austria, France, the Netherlands and the United Kingdom have substantially reduced their tax rates. Second, the spread in corporate tax rates between countries has been reduced. Third, there was substantial variation in tax rates within and between countries, especially during the 1980s.

\section{Econometric specification and estimation results}

The functional form of the transfer-pricing response to taxes $e\left(\tau^{D}\right)$ is assumed to take the form a price mark-up which varies linearly in the deviation between country specific and average tax rates. Equation (3.2) is used as the basis for the following estimating equation:

$$
V_{i j t}=c_{c s t} *\left(1+\gamma_{c s} \bar{\tau}_{i j t}^{D}\right)+\epsilon_{i j t},
$$

where $V_{i j t}$ is the observed value-labor ratio in country $i$, sector $j$ and time period $t$, and where

$$
c_{c s t}=c+\sum_{d=2}^{N_{c}} c_{d}^{c}\left(I_{d, i j t}^{c}-I_{1, i j t}^{c}\right)+\sum_{d=2}^{N_{s}} c_{d}^{s}\left(I_{d, i j t}^{s}-I_{1, i j t}^{s}\right)+\sum_{d=2}^{N_{\tau}} c_{d}^{\tau}\left(I_{d, i j t}^{\tau}-I_{1, i j t}^{\tau}\right),
$$

where $I_{d, i j t}^{c}$ is an indicator that equals 1 if observation ijt belongs to country $d$, and equals 0 otherwise; $I_{d, i j t}^{s}$ is an indicator that equals 1 if observation $i j t$ belongs to sector $d$, and equals 0 otherwise; $I_{d, i j t}^{\tau}$ is an indicator that equals 1 if observation $i j t$ belongs to year $d$, and equals 0 otherwise. Further, $\bar{\tau}_{i j t}^{D}$ (measured in percentage points) is the difference between the headline corporate tax rate in sector $j$ of country $i$ at time $t$ from the weighted average of headline taxes of all countries in the sample. ${ }^{6}$ Although profit shifting may be affected by the presence of other taxes and cross-country differences between them, at the margin the gain from shifting an additional dollar should for a large part be determined by the difference in headline corporate tax rates. In different specifications the coefficients $c$ and $\gamma$ are interacted with combinations of country, sector, and/or time dummies in order to sweep out fixed effects and to allow the sensitivity of transfer-pricing to taxes to vary by sector or country.

\footnotetext{
${ }^{6}$ For each sector, the average tax rate is computed using sectoral production as relative weights. For this reason, $\bar{\tau}^{D}$ varies slightly between sectors in a country. The consideration was that transfer-pricing takes place between affiliates within a sector, owing to taxes differing from those in relevant countries. The weighting scheme, however, does not appreciably alter our results.
} 
The estimating equation for the CES production function is based on equation $(3.3)$ :

$$
V_{i j t}=\left[1+c_{c s t}^{1 /(\rho-1)}\left(\frac{\tilde{r}_{i j t}}{w_{i j t}}\right)^{\rho /(\rho-1)}\right]\left(1+\gamma_{c s} \bar{\tau}_{i j t}^{D}\right)+\epsilon_{i j t},
$$

with $c_{c s t}$ as given above. The user cost of capital is given by $\tilde{r}_{i j t}=P_{I, i t} \frac{r_{i t}+\theta-\dot{q}_{i t}}{1-\tau_{i t}}(1-$ $\left.\tau_{Z, i t}\right)$, where $r$ is the long-term interest rate, $P_{I}$ is the investment deflator, $\theta$ is the depreciation rate, $\dot{q}$ is the expected appreciation of capital, $\tau$ is the corporate tax rate and $\tau_{Z}$ is the present discounted tax value of depreciation deductions. In the empirical work, $\theta=0.08$, and $\tau_{Z}$ is calculated assuming static expections on future tax rates, a constant discount rate $(6 \%)$, and geometric depreciation (12 year life).

\subsection{Baseline results}

Table 1 summarizes our main results. In case A, the sensitivity of the valuelabor ratio with respect to the tax changes is allowed to vary across countries. The rationale for having $\gamma$ vary over countries is that countries may differ in the enforcement of the transfer pricing rules. In addition, in some countries economic activity may be relatively more concentrated than in other countries in sectors where the scope for profit shifting is larger. The estimate of $\gamma$ reported in the table is the average of the estimates over the countries. The average estimate for $\gamma$ is negative and highly significant, indicating that an individual increase in the corporate tax rate leads to a shift of reported profits to the other OECD countries. Profit shifting in response to tax rate changes seems to be particularly important for Spain, Japan and Portugal.

The size of the shift in reported profits is large. Table 2 presents a back-of-the envelope calculation of the effect of a unilateral one-percentage point increase in the headline corporate tax rate on profits before taxes and on total corporate tax revenues. The calculation is based on the case of a Cobb-Douglas production function with $\gamma$ varying across countries (case A in Table 1). The calculation assumes an equity/total assets ratio of 0.5 and a corporate tax rate of $37.5 \%$. The equity/total assets ratio is the unweighted average of the corresponding numbers of the G7 counties for 1991 as reported in Rajan and Zingales (1995). ${ }^{7}$ The corporate tax rate is the unweighted average of the $\mathrm{G} 7$ headline rates. At the

\footnotetext{
${ }^{7}$ Table III, panel A, in Rajan and Zingales (1995) reports averages of nonequity liabilities to total asset ratios for the G7 countries. The numbers are based on consolidated balance sheets in 1991 of samples of non-financial firms. We use the column based on market values and compute the equity/total assets ratios as 0.56 for the U.S., 0.55 for Japan, 0.44 for Germany, 0.39 for France, 0.33 for Italy, 0.58 for the U.K. and 0.53 for Canada. The unweighted average is 0.48 , which is close to our baseline number of 0.5 .
} 
margin, net returns (possibly adjusted for differences in risk) on debt and equity should be equated. Because it is hard to obtain a reliable figure for the effective tax rate on interest income, we simply assume that interest income at the personal level is taxed at the same rate as corporate profits. With an equity/total assets ratio of 0.5 and equal net returns on debt and equity, in the initial situation, half of what is left over after compensating labor should go to debt providers. The table shows that an increase in the tax rate reduces corporate tax revenues, although the reduction is quite small. In the absence of profit shifting (hence, reported profits are not affected by the tax increase), corporate tax revenues would have risen to 7.315. Hence, the percentage of revenues due to shrinkage of the (reported) tax base is $2.7 \% .^{8}$ Although these figures should be seen only as rough estimates, given the assumptions that we made, they give an indication of the possible order of magnitude of profit shifting in reality.

Some potential indirect support for these results can be obtained by inspecting corporate tax rates and corporate income tax revenues as a share of GDP. Figure 6.2 plots revenues as a share of GDP averaged over the period 1979-1997 against the average tax rate over the same period. ${ }^{9}$ Although the number of data points is small, there seems to be no correlation between average tax rates and average revenues. In particular, higher tax rates do not seem to result in higher revenues, on average. A regression of tax revenues on tax rates yields a coefficient that is negative, but insignificantly different from zero. Interestingly, of the four biggest economies in Europe, Germany has by far had the highest average corporate tax rate $(52.7 \%$, versus $41.7 \%$ for France, $33.8 \%$ for Italy and $39 \%$ for the U.K.), but the lowest average corporate tax revenue as a share of GDP (1.83\% versus $2.05 \%$ for France, $3.35 \%$ for Italy and $3.38 \%$ for the United Kingdom). To what extent these findings can be attributed to profit shifting is an open issue. There are many other channels through which (reported) profits can be reduced, such as outright tax evasion and extensive debt financing of subsidiaries in high-tax countries. However, because the revenue figures are expressed as shares of GDP, they are unlikely to be driven by real activity shifts. A lower tax rate would draw in more capital, thereby raising both national profits and GDP.

Intuitive reasoning might suggest that a tax increase has a stronger effect on profit shifting when corporate tax rates are already high than when they are low.

\footnotetext{
${ }^{8}$ If we assume that interest income is untaxed at the personal level, this figure falls to $2.2 \%$. To compute this figure, combine the assumption that the debt/total assets ratio is 0.5 with the requirement that the net returns on equity and debt are equal, to find that the compensation for debt holders in Table 2 falls to 14.62 (which equals the initial after-tax compensation for the shareholders).

${ }^{9}$ For a number of countries revenue data were only available for a subsample of this period. In each case the largest possible subsample has been taken. Source: Table/Figure A17 in Eurostat (1998).
} 
To see whether the estimated $\gamma$ differs systematically with the level of the corporate tax rate, Figure 6.3 plots for each country $\hat{\gamma}$ against the average corporate tax rate over the sample period. There is no systematic pattern and a regression of $\hat{\gamma}$ on the average corporate tax rate yields insignificant coefficients. Although country-specific effects could disturb a possible relation between $\hat{\gamma}$ and the corporate tax rate, the use of country-specific fixed effects in our regressions should mitigate this possibility. Apart from the small sample size (16 obervations), an explanation for the lack of a relationship could be that countries with higher corporate tax rates also put more effort in the enforcement of the transfer pricing rules.

Case B in Table 1 shows the estimates for the CES production function when $\gamma$ is allowed to vary over countries. The estimates for $\gamma$ are very similar to those for the Cobb-Douglas production function. The estimate for $\rho$ yields a point estimate of $\hat{\sigma}=1 /(1-\hat{\rho})=1.04$ for the elasticity of substitution between capital and labor. Hence, substitutability between capital and labor is barely stronger than for a Cobb-Douglas production function.

Table 1 also gives the average estimate for $\gamma$ when $\gamma$ is allowed to vary across sectors (cases $\mathrm{C}$ and $\mathrm{D}$ ). The motivation for allowing $\gamma$ to vary across sectors is that the scope for shifting income may differ systematically across sectors. For example, a priori, one would expect extensive profit shifting in sectors dominated by large multinationals and a lot of intra-industry trade. For those sectors, a given deviation of the transfer price from the arm's length price implies a larger shift in profits. Similarly, one would expect that in sectors where intangibles (for example, intellectual property rights) are more important, profit shifting is more prevalent (this is also confirmed by the model in Appendix A). The reason is that it is relatively difficult to establish the proper arm's length price for intangibles, so that the margin for the manipulation of intrafirm prices is larger. The estimate of $\gamma$ now drops, but it is still highly significant and the amount of tax revenue lost from profit shifting is still large. Following the example in Table 2, the drop in corporate tax revenues (compared to when profit shifting is absent) resulting from a unilateral one-percentage point increase in the tax rate is now estimated at $1.5 \%$. The sectors where profit shifting seems to be largest are Industrial Chemicals (S3510), Other Chemicals (S3520), Iron and Steel (S3710) and Non-Ferrous Metals (S3720). "Other Chemicals" also includes pharmaceutical products, for which R\&D and, hence, intellectual property are relatively important.

\subsection{Robustness check}

We now address how robust our estimates of the sensitivity of profit shifting with respect to tax rate differences are for different assumptions about the presence 
of fixed country, sector or time effects. Because the substitutability of capital and labour estimated for a CES production function barely differed from the substitutability under a Cobb-Douglas specification and because the estimates for $\gamma$ in both cases were very close, Table 3 reports the results only for the CobbDouglas specification. As for the baseline results, generally the strongest effects of tax rate differences on the value-labor ratio are obtained if $\gamma$ is allowed to vary over countries rather than over sectors. In almost all of the cases $\hat{\gamma}$ remains (highly) significant at conventional confidence levels.

\section{Conclusion}

We have investigated for OECD countries to what extent differences in tax rates lead to profit shifting (which is unrelated to shifts in real activity). In contrast to most of the preceding literature, which uses either macroeconomic data or firmlevel data, our empirical analysis was based on sectoral data. Our results indicate that the size of profit shifting is significant and large: a back-of-the-envelope calculation for our baseline estimate suggests that, on average, a unilateral onepercentage point increase in the tax rate leads to a three percent fall in corporate tax revenues compared the case in which the tax base, (reported) corporate profits, is unchanged. Our results are robust over a wide variety of empirical specifications. Moreover, assuming CES instead of Cobb-Douglas production technology, and thus allowing for shifts in factor shares in response to changes in the wage-rental ratio, does not affect our results. The degree of substitutability between labor and capital differs statistically compared with Cobb-Douglas technology. However, quantitatively speaking, the difference is very small.

We need to emphasize that our estimates, if correct, are likely to constitute only a lower bound on the effect of tax rate changes on reported profits. First, besides transfer pricing, there are other channels for shifting profits. One prominent channel is the extensive use of debt contracts between related parties in different countries. Second, our empirical analysis has abstracted from the possibility of real activity shifts (which affects the amount of capital and, thus, the scale at which operations take place). With data on capital stocks, one could, in principle, also estimate the effect of tax rate changes on real activity. The outcomes from such an analysis should be interpreted with care, though, because many countries in our sample have undergone major structural economic reforms of which the effect on real activity may be hard to determine.

Our results suggest that, in principle, the revenues from stricter enforcement of the rules on transfer pricing can be quite high. However, the scope for transfer pricing, or profit shifting in general, within a multinational is tightly linked to the scale at which it operates. Tighter enforcement of the rules in a high-tax 
country means that the net return on investments falls and, hence, it carries the risk that real activity is shifted to other countries with lower taxes or laxer enforcement. ${ }^{10}$ Therefore, enforcement of transfer pricing rules is typically a case where international coordination may be needed. Examples are the exchange of information about the activities of multinationals and agreements about minimum enforcement standards or common transfer prices (for example, see Mansori and Weichenrieder, 1999).

\section{References}

[1] Bartelsman, Eric J. and Mark Doms, 2000, Understanding Productivity: Lessons from Longitudinal Micro Data, Journal of Economic Literature, (forthcoming, September 2000).

[2] Birnie, J.E., 1996, Comparative Productivity in Ireland: The Impact of Transfer Pricing and Foreign Ownership, in Wagner, K. and B. van Ark (eds.), International Productivity Differences; Measurement and Explanations, Elsevier, Amsterdam.

[3] Eurostat, 1998, Structures of the Taxation Systems in the European Union 1970-1996, European Communities, Luxembourg.

[4] Grubert, Harry, 1998, Taxes and the Division of Foreign Operating Income among Royalties, Interest, Dividends and Retained Earnings, Journal of Public Economics 68, 269-90.

[5] Grubert, Harry and John Mutti, 1991, Taxes, Tariffs and Transfer Pricing in Multinational Corporate Decision Making, Review of Economics and Statistics 68, 285-93.

[6] Grubert, Harry and Joel Slemrod, 1998, The Effect of Taxes on Investment and Income Shifting into Puerto Rico, Review of Economics and Statistics $75,365-73$.

\footnotetext{
${ }^{10}$ In 1992, Germany imposed a restriction that linked the amount of German-tax exempt passive income generated by Irish subsidiaries of German multinationals to the amount of active income generated by the Irish subsidiaries. Weichenrieder (1996) argues that this could well have induced German multinationals to start using these subsidiaries (which were originally set up for financial investment purposes) for local production, thereby shifting real activity from Germany to Ireland.
} 
[7] Harris, David G., 1993, The Impact of U.S. Tax Law Revision on Multinational Corporations' Capital Location and Income-Shifting Decisions, Journal of Accounting Research 31 (Supplement), 111-40.

[8] Hines, James R., 1996a, Altered States: Taxes and the Location of Foreign Direct Investment in America, American Economic Review 86, 1076-1094.

[9] Hines, James R., 1996b, Tax Policy and the Activities of Multinational Corporations, NBER Working Paper, No.5589.

[10] Hines, James R. and Eric M. Rice, 1994, Fiscal Paradise: Foreign Tax Havens and American Business, Quarterly Journal of Economics 109, 149-82.

[11] Mansori, Kashif S. and Alfons J. Weichenrieder, 1999, Tax Competition and Transfer Pricing Disputes, Mimeo, Colby College and CES.

[12] Newlon, T. Scott, 1997, Transfer Pricing and Income Shifting in Integrating Economies, mimeo, U.S. Department of the Treasury.

[13] OECD Statistics, 1999, The OECD STAN Database for Industrial Analysis, OECD, Paris.

[14] Rajan, Raghuram G. and Luigi Zingales, 1995, What Do We Know about Capital Structure? Some Evidence from International Data", Journal of Finance 50, 5, 1421-1460.

[15] Roeger, Werner, 1995, Can Imperfect Competition Explain the Difference between Primal and Dual Productivity Measures? Estimates for US Manufacturing, Journal of Political Economy 103, 2, 316-330.

[16] Weichenrieder, Alfons J., 1996, Fighting International Tax Avoidance: The Case of Germany, Fiscal Studies 17, 1, 37-58.

\section{Appendix A: A microfoundation for (3.2)}

Consider a world with two countries, $A$ and $B$. There is a continuum of allequity financed multinationals on the interval $[0,1]$. Companies are identical in all respects, except that they may differ in the location of final good production. Multinationals $[0, n]$ reside and produce in $A$, while mutinationals $(n, 1]$ reside and produce in $B$. Their production functions are respectively: 


$$
Q_{A}=L_{A}^{\alpha} K^{1-\alpha} \text { and } Q_{B}=L_{B}^{\alpha} K^{1-\alpha},
$$

where $L_{A}$ and $L_{B}$ are labor inputs and $K$ is capital. Production requires the use of an intangible which is in fixed supply $H$. The intangible can, for example, be the patent on a production process. It is owned by an affiliate of the multinational located in the country other than where the production of the final good takes place.

Multinationals maximize the sum of after-tax profits (minus a fine for profit shifting) in each of the countries where they are active. Both countries use the exemption system for residents' income generated abroad. Hence, multinationals $[0, n]$ from country $A$ maximize:

$$
\begin{aligned}
\pi^{m} & \equiv\left(1-\tau_{A}\right) \pi_{A}+\left(1-\tau_{B}\right) \pi_{B}-f\left(\gamma_{A}\right) \\
& =\left(1-\tau_{A}\right)\left[P L_{A}^{\alpha} K^{1-\alpha}-w L_{A}-z_{A}^{T} H\right]+\left(1-\tau_{B}\right) z_{A}^{T} H-f\left(\gamma_{A}\right),
\end{aligned}
$$

where $P_{f}$ is the final good price and $w$ is the wage rate. Both are equal across the two countries. Further, $\tau_{i}$ is the tax rate in country $i(i=A, B) \cdot z_{A}^{T}=z\left(1+\gamma_{A}\right)$ is the price charged for the use of the intangible. Here, $z$ is the arm's length (market) price, while $\gamma$ is a markup imposed in order to shift income across borders. Finally, $f\left(\gamma_{A}\right)$ is a penalty (a fine) for the use of the incorrect transfer price. We assume that $f^{\prime}\left(\gamma_{A}\right)=0$ for $\gamma_{A}=0$. Moreover, $f$ is positive and strictly convex in $\gamma_{A}$, to indicate that the fine increases more than proportionally in the size of the markup and/or to indicate that the chances of being caught are increasing in the size of the markup.

The first-order conditions with respect to $L_{A}$ and $\gamma_{A}$ are, respectively:

$$
\begin{aligned}
\alpha P_{f} L_{A}^{\alpha-1} K^{1-\alpha} & =w, \\
\left(1-\tau_{A}\right)(-z H)+\left(1-\tau_{B}\right) z H & =f^{\prime}\left(\gamma_{A}\right),
\end{aligned}
$$

Hence, specifying $f\left(\gamma_{A}\right)=\frac{1}{2} \gamma_{A}^{2}$,

$$
\begin{aligned}
w L_{A} & =\alpha P_{f} Q_{A} \\
\left(\tau_{A}-\tau_{B}\right) z H & =\gamma_{A} .
\end{aligned}
$$

In other words, the larger the tax rate differential $\tau_{A}-\tau_{B}$ between the two countries, the higher the markup and thus the larger the amount of profit shifting from $A$ to $B$. 
Multinationals with production located in $B$ maximize:

$$
\pi^{n}=\left(1-\tau_{B}\right)\left[P_{f} L_{B}^{\alpha} K^{1-\alpha}-w L_{B}-z_{B}^{T} H\right]+\left(1-\tau_{A}\right) z_{B}^{T} H-f\left(\gamma_{B}\right)
$$

where $z_{B}^{T}=z\left(1+\gamma_{B}\right)$ and $f\left(\gamma_{b}\right)=\frac{1}{2} \gamma_{B}^{2}$. Going through the optimization procedure now yields:

$$
\begin{aligned}
w L_{B} & =\alpha P_{f} Q_{B}, \\
\left(\tau_{B}-\tau_{A}\right) z H & =\gamma_{B} .
\end{aligned}
$$

Hence, $\gamma_{B}=-\gamma_{A}$.

Using these results, we can now derive the ratio of total (of all firms) value added $(T V A)$ and total labor compensation $(T L C)$. For country $A$ it is given by:

$$
\begin{aligned}
\frac{T V A}{T L C} & =\frac{n\left[P_{f} L_{A}^{\alpha} K^{1-\alpha}-z\left(1+\gamma_{A}\right) H\right]+(1-n) z\left(1+\gamma_{B}\right) H}{n \alpha P_{f} L_{A}^{\alpha} K^{1-\alpha}} \\
& =\frac{1}{\alpha}+\frac{-n z\left(1+\gamma_{A}\right) H+(1-n) z\left(1-\gamma_{A}\right) H}{n \alpha P L_{A}^{\alpha} K^{1-\alpha}} \\
& =\frac{1}{\alpha}+\frac{(1-2 n) z H-z \gamma_{A} H}{n \alpha P_{f} L_{A}^{\alpha} K^{1-\alpha}} \\
& =\frac{1}{\alpha}+\left[\frac{(1-2 n) z}{n \alpha P_{f} L_{A}^{\alpha} K^{1-\alpha}}\right] H-\gamma_{A}\left[\frac{z H}{n \alpha P_{f} L_{A}^{\alpha} K^{1-\alpha}}\right] \\
& =\frac{1}{\alpha}+\left[\frac{(1-2 n) z}{n \alpha P_{f} L_{A}^{\alpha} K^{1-\alpha}}\right] H-\left[\frac{z^{2}}{n \alpha P_{f} L_{A}^{\alpha} K^{1-\alpha}}\right] H^{2}\left(\tau_{A}-\tau_{B}\right),
\end{aligned}
$$

This expression leads to the following empirical predictions. First, an increase in the tax difference $\tau^{D} \equiv \tau_{A}-\tau_{B}$ implies a reduction in $\frac{T V A}{T L C}$. Second, the reduction for a given increase in $\tau^{D}$ is larger, the larger the amount of intangibles, $H$. 


\section{Appendix B: The data}

Countries included:

Australia, Austria, Belgium, Canada, Denmark, Finland, France, Germany, Italy, Japan, the Netherlands, Portugal, Spain, Sweden, the United Kingdom and the United States.

Industries included:

ISIC Rev.2 Description

$3100 \quad$ Food, beverages, tobacco

$3200 \quad$ Textiles, wearing apparel, leather and leather products, footwear

$3300 \quad$ Wood products, furniture and fixtures

$3400 \quad$ Paper products, printing and publishing

$3510 \quad$ Industrial chemicals

$3520 \quad$ Other chemicals

$3600 \quad$ Pottery and china, glass products, non-metallic products nec

$3710 \quad$ Iron and steel

$3720 \quad$ Non-ferrous metals

$3810 \quad$ Metal products

$3820 \quad$ Machinery nec

$3830 \quad$ Electrical machinery

$3840 \quad$ Transport equipment

$3850 \quad$ Professional goods

$3900 \quad$ Other manufacturing 


\section{Tables}

Table 1: Baseline estimates

\begin{tabular}{|l|l|l|l|l|l|l|l|}
\hline case & $\gamma$ varies by & prod. function & $\hat{c}$ & $\hat{\gamma}$ & $\hat{\rho}$ & $R^{2}$ & $S S E$ \\
\hline A & country & Cobb-Douglas & 1.61 & -.0052 & & 0.49 & 0.13 \\
\hline & & & $(.0097)$ & $(.0012)$ & & & \\
\hline B & country & CES & 3.61 & -.0049 & 0.04 & 0.59 & 0.11 \\
\hline & & & $(.45)$ & $(.0010)$ & $(.0092)$ & & \\
\hline C & sector & Cobb-Douglas & 1.62 & -.0029 & & 0.49 & 0.13 \\
\hline & & & $(.0062)$ & $(.0008)$ & & & \\
\hline D & sector & CES & 2.70 & -.0035 & 0.03 & 0.58 & 0.11 \\
\hline & & & $(.33)$ & $(.0007)$ & $(.0092)$ & & \\
\hline
\end{tabular}

Notes: (1) "prod. function" = production function, $\hat{c}=$ estimate of $c, \hat{\gamma}=$ estimate of $\gamma$ (averaged over country- or sector-varying parameters, whenever relevant), $\hat{\rho}=$ estimate of $\rho, S S E=$ standard error of regression.

(2) Numbers of observations is 4100.

(3) Sample period is 1979-1997.

Table 2: Effect of a unilateral tax rate increase

\begin{tabular}{|l|l|l|}
\hline & initial rate $=37.5 \%$ & new rate $=38.5 \%$ \\
\hline value-added & 100 & $(1-\hat{\gamma}) * 100=99.48$ \\
\hline labor share is $\hat{c}^{-1}=1.61^{-1}$ & -62 & -62 \\
\hline compensation debt providers & $-0.5(100-62)=-19$ & -19 \\
\hline & & \\
\hline (reported) profits before taxes & 19 & 18.48 \\
\hline corporate tax revenue & $0.375 * 19=7.125$ & $0.385 * 18.48=7.115$ \\
\hline
\end{tabular}

Notes: assumed ratio of debt to total assets is 0.5. Because employment and debt contracts are given, compensation for labor and debt providers remains unchanged with the tax increase. 
Table 3: Robustness check (Cobb-Douglas).

\begin{tabular}{|l|l|l|l|l|l|}
\hline$c_{c s t}$ & $\gamma$ varies by & $\hat{\gamma}$ & s.e. & $R^{2}$ & $S S E$ \\
\hline constant & constant & -.0075 & .00072 & .025 & 0.25 \\
\hline constant & $c$ & -.011 & .0012 & .070 & 0.24 \\
\hline constant & $s$ & -.0075 & .00072 & .038 & 0.25 \\
\hline$c$ & constant & -.0021 & .00096 & 0.21 & 0.20 \\
\hline$c$ & $c$ & -.0031 & .0015 & 0.21 & 0.20 \\
\hline$c$ & $s$ & -.0017 & .00094 & 0.23 & 0.20 \\
\hline$s$ & constant & -.0078 & .00062 & 0.28 & 0.18 \\
\hline$s$ & $c$ & -.012 & .0010 & 0.34 & 0.17 \\
\hline$s$ & $s$ & -.0075 & .00065 & 0.29 & 0.18 \\
\hline$t$ & constant & -.0077 & .00074 & .045 & 0.24 \\
\hline$t$ & $c$ & -.0089 & .0013 & 0.11 & 0.23 \\
\hline$t$ & $s$ & -.0077 & .00073 & .058 & 0.24 \\
\hline$c, s$ & constant & -.0030 & .00078 & 0.46 & 0.14 \\
\hline$c, s$ & $c$ & -.0062 & .0012 & 0.47 & 0.14 \\
\hline$c, s$ & $s$ & -.0022 & .00082 & 0.47 & 0.14 \\
\hline$c, t$ & constant & -.0028 & .00099 & 0.23 & 0.20 \\
\hline$c, t$ & $c$ & -.0022 & .0016 & 0.23 & 0.20 \\
\hline$c, t$ & $s$ & -.0022 & .00098 & 0.24 & 0.19 \\
\hline$s, t$ & constant & -.0080 & .00063 & 0.30 & 0.18 \\
\hline$s, t$ & $c$ & -.010 & .0011 & 0.37 & 0.16 \\
\hline$s, t$ & $s$ & -.0077 & .00065 & 0.31 & 0.18 \\
\hline$c, s, t$ & constant & -.0037 & .00080 & 0.48 & 0.13 \\
\hline & & & &
\end{tabular}

Notes: (1) In the first column, $c=$ country dummies, $s=$ sector dummies and $t=$ time dummies. (2) In the second column, $c=\gamma$ varies by country and $s=\gamma$ varies by sector. (3) $\hat{\gamma}=$ estimate of $\gamma$ (averaged over countries or sectors, when relevant), s.e. $=$ standard error of $\hat{\gamma}, S S E=$ standard error of regression. (4) Number of observations is 4100 . 


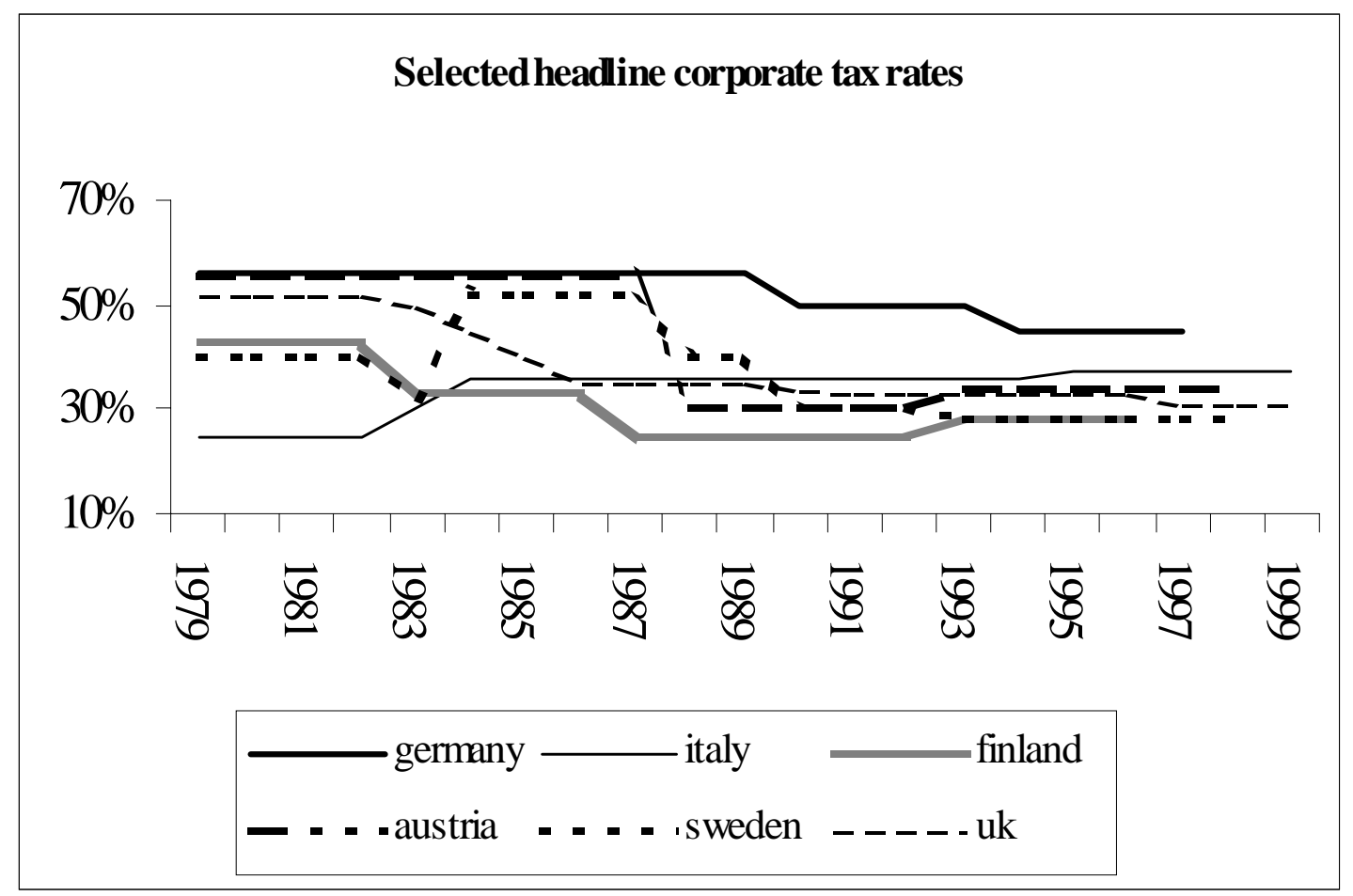

Figure 6.1: 


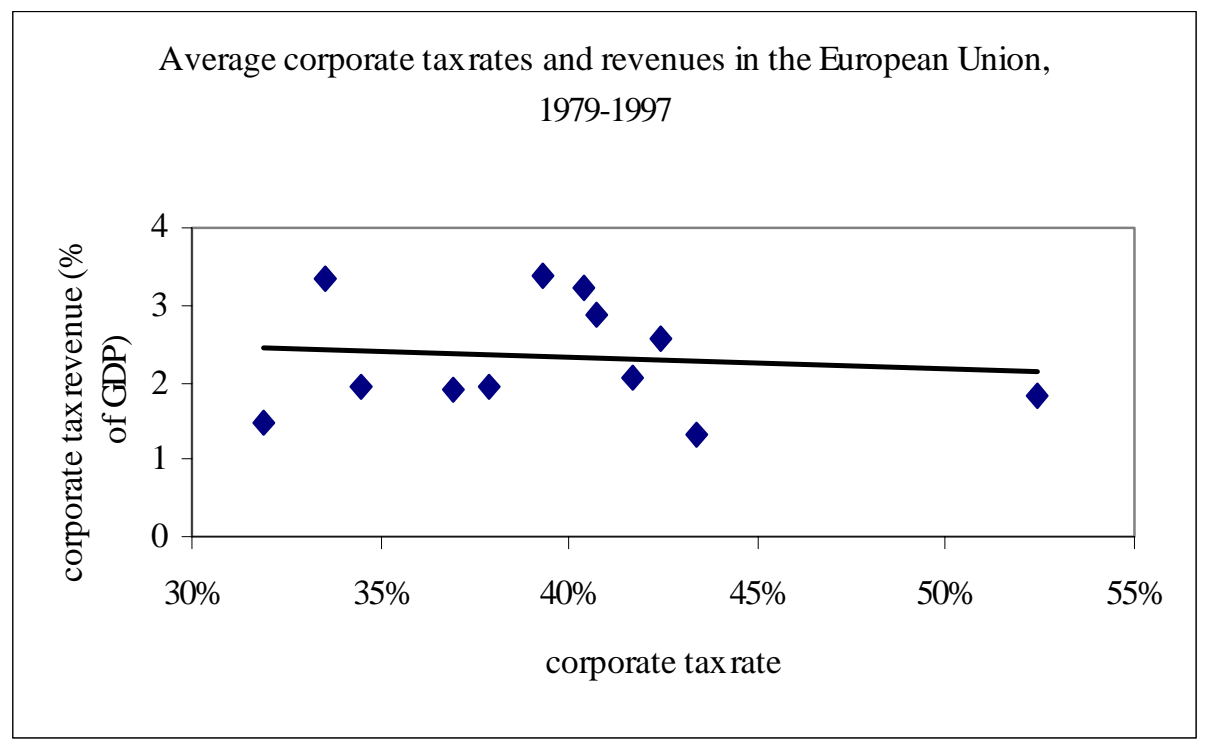

Figure 6.2:

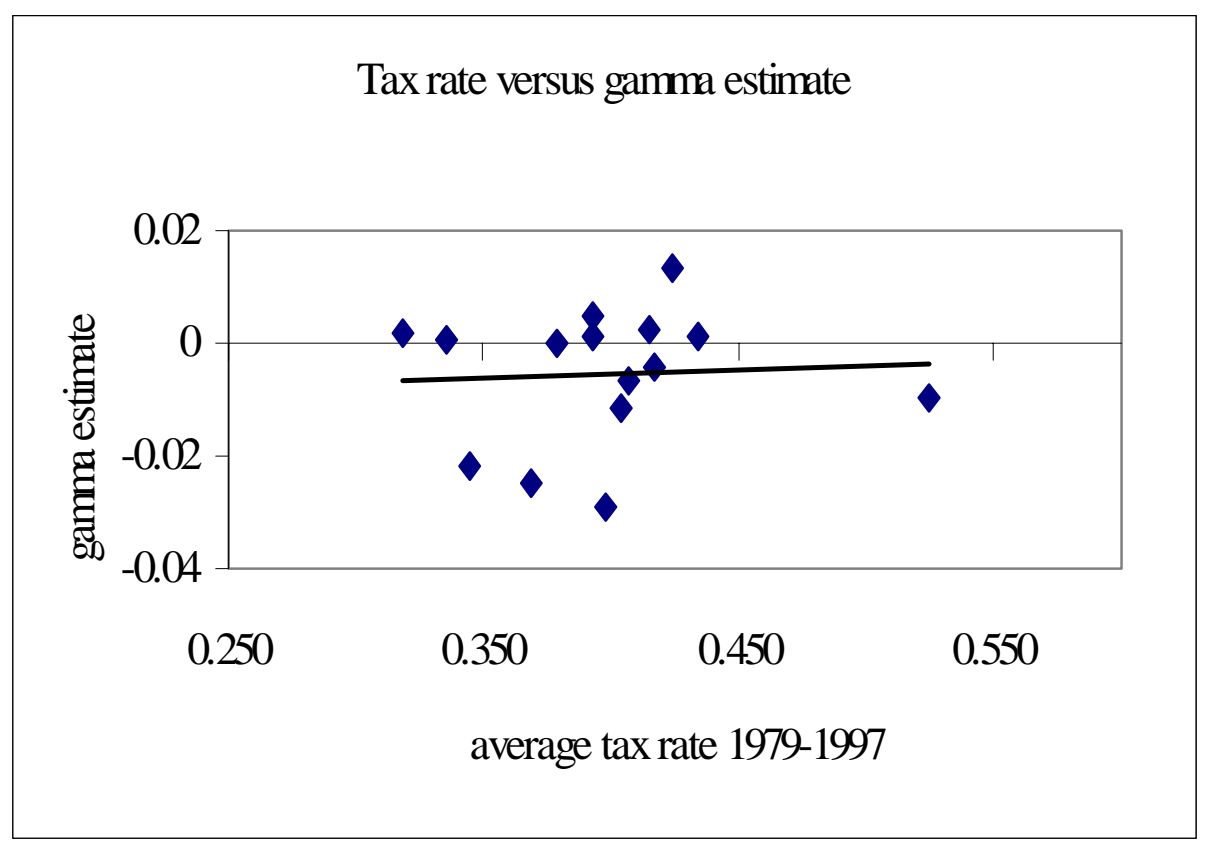

Figure 6.3: 